\title{
Materialism As Intentionalism: on the Possibility of a "New Materialist” Literary Criticism
}

In this article, I draw on the work of authors associated with New Materialism(s) and the material turn, in order to examine and compare various ways of developing a "new materialist" literary criticism/literary theory. I then set these projects against a more traditional historical materialist perspective, as exemplified for instance by Fredric Jameson, in order to point out some fundamental differences between literary criticism focused on the imagined "true" materiality of the text and one that chooses to emphasise instead the inherent materiality of the work of literature as such (on all its levels). Here, the oft-discussed Marxist distinction between the base and the superstructure provides a good example of how these two approaches, though ostensibly similar, may in fact represent two very different, even contradictory schools of thought and criticism.

My goal is not to criticise new materialists for not maintaining some imagined Marxist dogma, but rather, to point out how a nominal attachment to the materiality of text, when combined with a desire to invent a new method of reading, may result in a point of view that, even on its own terms, cannot be seen as materialist.

Drawing on Fredric Jameson's remarks on materialist criticism as a work of "demystification and de-idealisation” rather than a "positive" method, I then refer to the work of Walter Benn Michaels as an example of "negative” materialist criticism that, instead of providing us with a new way of "doing interpretation", allows us to de-idealize the way we discuss literature.

Keywords: materialism, idealism, intentionalism, Marxism, literary criticism, base, superstructure 


\section{Jameson, or Materialism as a Polemic Stance}

What does it mean to approach literary criticism from a materialist perspective? This question, complicated as it is, must be today posed in the context of the so-called new materialisms and the "material(ist) turn"- - two largely (although not strictly) interchangeable terms that, in the last few decades, came to signify a loose network of ideas and concepts based on the renewed academic and artistic interest in such things as non-human agency (and the agency of things), the "materiality of matter" (or the life of matter itself), posthuman and hybrid subjectivity, or the relationship between politics and quantum physics. In a way, what changed is the starting point of any serious attempt at a definition: we can no longer associate "materialist criticism" by default with a focus on social history, class struggle, commodity fetishism and so on. Moreover, a certain sensitivity present in many of the new materialist writings- a general focus on the fluid, the diffractive, and the vibrant, owed largely to Deleuze and Guattari-may seem at odds with a more traditional historical-materialist approach. Indeed, the tension between Marxism and new materialisms has already resulted in a large body of academic work (see e.g. Bednarek 2018, Torrent 2014).

But the question of what it means to be a materialist critic has been always complicated, in no small part due to the fact that materialism itself — as a philosophy, practice or movement- never seemed to have a clearly defined, positive meaning. That's why, in Marx's Purloined Letter, Fredric Jameson famously suggested that the very notion of "materialism" should be seen primarily as a way of organising struggle, rather than an independent philosophical category:

As for materialism, it ought to be the place in which theory, deconstruction and Marxism meet: a privileged place for theory, insofar as the latter emerges from a conviction as to the "materiality" of language; for deconstruction insofar as its vocation has something to do with the destruction of metaphysics; for Marxism ("historical materialism") insofar as the latter's critique of Hegel turned on the hypostasis of ideal qualities and the need to replace such invisible abstractions by a concrete (that included production and economics). It is not an accident that these are all negative ways of evoking materialism.

Rather than conceiving of materialism as a systematic philosophy, it would seem possible and perhaps more desirable to think of it as a polemic stance, designed to organize various anti-idealist campaigns, a procedure of demystification and de-idealization; or else a permanent linguistic reflexivity. This is, among other things, why Marxism has never been a philosophy as such, but 
rather a "unity-of-theory-and-practice" very much like psychoanalysis, and for many of the same reasons. (Jameson 1995, 84)

Materialism is thus a name we have come to use, under various social and historical circumstances, in order to link together the varied and possibly scattered "campaigns" against the idealist illusion(s). Indeed, as a conscious practice - rather than, say, a default way of being in the world-materialism is (and can be) nothing more than a critical reaction to idealism. This is not a historical or an institutional issue-materialism is negative by the very nature of the term. And strictly speaking, this is an issue of terms and names: as long as you need to call yourself a "materialist," this is only because there's an idealist tendency that you need to differentiate yourself from. Jameson further elaborated on this idea in the expanded version of Marx's Purloined Letter, included in the Valences of Dialectic:

These dilemmas are exacerbated if we think, not in terms of consciousness as the older philosophies did, but in terms of language: where the notion of writing a materialist sentence already offers something of a paradox, at least insofar as it suggests that you might also be able to write "idealist" sentences. But probably those philosophically unacceptable sentences are merely sentences whose necessary linguistic materiality we have forgotten or repressed, imagining them to be somehow pure thought. In that case, "materialism" would simply involve reminding ourselves at every turn that we are using words (rather than thinking pure thoughts or having "experiences" of consciousness) (...) In either case, materialism would seem precluded as a philosophy: at best it could be a polemic slogan, designed to organize various anti-idealist campaigns, a procedure of demystification and de-idealization; or else a permanent linguistic reflexivity. This is, among other things, why Marxism has never been a philosophy as such, but rather a "unity of theory and practice" very much like psychoanalysis, and for many of the same reasons. (Jameson 2009, 140)

Instead of a "polemic stance," Jameson now sees materialism as a "polemic slogan," in a shift that seems to further weaken the autonomy of materialism as a distinct philosophical position or methodology. But even more instructive is the example of language, and the (im)possibility of making "idealist sentences." One cannot write a "materialist sentence" in the sense of writing a sentence that is, in its materiality, ontologically distinct from some other sentences; instead, materialism reminds us of the "forgotten or repressed" materiality that's always already there. This is why the inherent negativity of materialist criticism seems to always take the shape of "demystification." Rather than rejecting that which is

Materialism is thus a name we have come to use, under various social and historical circumstances, in order to link together the varied and possibly scattered "campaigns" against the idealist illusion(s). Indeed, as a conscious practice-rather than, say, a default way of being in the world-materialism is (and can be) nothing more than a critical reaction to idealism. 
not material, a materialist perspective reminds us that everything is material; and, rather than criticising idealism for stealing the world, materialists criticise it for stealing people's minds. Idealism is a con-man rather than a conqueror.

There's an obvious, yet somewhat counterintuitive conclusion, to be derived from Jameson's remarks. Whereas materialism in general, as an inherently political movement, is famously action-oriented and calls for the "unity of theory and practice," when it comes to commenting on language as such — which, one supposes, must include analysing and interpreting literary texts-materialism seems to call for certain restraint. The task of a materialist critic is to remind and recall, to point out the inherent materiality of language, rather than try and make the texts somehow "more" material; there's after all only so much you can do by changing the way people think about language. This is a genuinely refreshing approach in the field that seems today largely focused on making itself more "performative" in the sense of rethinking the practice of literary criticism so it may become more direct in its impact on the material world. Here, Jameson's remarks reinforce the idea that a sense of political urgency should never make us blind to the essential limitations of our own discipline and practice.

If materialist philosophy (necessarily) lacks a clear positive definition, then things tend to get even murkier once we move to the field of literary theory and criticism. Not only has the Marxist tradition produced, over the years, a multitude of wildly different approaches to the central tenets of literary theory, it also lacks, in a way, a single shared source. Despite valuing literature highly, Marx and Engels have famously never offered a coherent and explicit "starting point" for Marxist literary studies, no single work or concept on which a new tradition could be founded. This is why, as Daniel Hartley rightly notes in his brilliant introduction to the history of Marxist literary criticism, "Marx and Engels' ultimate influence on what became 'Marxist literary criticism' is less a result of these isolated fragments than the historical materialist method as such" (Hartley, n.d.). As a result, we should probably see historical materialism in literary studies less in terms of a separate tradition, and more as a political position shared by authors belonging to various movements, groups and even schools. This shared position would be again defined in negative terms: a general opposition to idealism as a tendency within literature and literary studies themselves.

In Materiality and Subject in Marxism, (Post-)Structuralism, and Material Semiotics, Johannes Beetz offers a criticism of new materialisms based on intuitions very similar to Jameson's: 
The multitude of papers and books published on the topic of materiality can by no means be said to constitute a field of research representing a homogenous theory or a common definition of what is to be included in the study of the "material."

However, many of them appear, despite their heterogeneity, to be united in an eerie preoccupation with "things" and "matter" and in a surprisingly persistent exclusion of certain fundamental kinds of materiality. This is, at least partly, due to a pervasive understanding of materiality which not infrequently reverts to a reductionist materialism by restricting materiality to matter or matter in motion. This notion, then, conceives of material entities either as passive objects waiting to be acted upon and manipulated, or alternatively as exerting a persistent effectivity, agency, or vitality of some sort. In the first case, material entities are sometimes regarded as materializations of the immaterial or ideational (like 'culture,' social relations, or identity). In the other extreme, as a persistent and effective part of reality, they impose themselves as extra-cultural and extra-social forces. Regarding the material as just one, albeit privileged, realm of existence while retaining the ideational in the form of "culture," "the subject," "language" or "thought" simply inverts idealism without abandoning its dichotomous categories. Furthermore, approaches to materiality that limit their inquiries to phenomena that consist of matter necessarily exclude modalities of materiality not readily identifiable as tangible, solid or given. (Beetz 2016, 3)

The "inverted idealism" of the new materialist thought seems to have a particular impact on the new materialist approach to literature-its peculiar dual status as both a repository of useful intuitions and illustrations, and the traditional domain of the non-material: the semantic, the discursive and the linguistic.

\section{Odradek, or the New Materialist Literary Criticism}

As Beetz rightly points out, the new materialists have, so far, by and large "disregarded" the "fundamental materiality of language and discourse" (Beetz 2016, 74), devoting little time or energy to the type of reflection on which both structuralism and post-structuralism have been founded. However, some efforts at imagining a specifically "new materialist" approach to literary criticism have been undertaken, and these efforts tend to produce quite a few problems of their own. Problems start, arguably, at the very beginning: with an attempt to root a new way of reading in a certain textual "enigma." Tobias Skiveren, one of the authors at newmaterialisms.eu —an online almanac dedicated to new 
materialisms_-gives us a good insight into this issue, by opening his entry on "literature" thus:

A spool of thread can neither run nor talk; and yet, it does both in Franz Kafka's short story "Cares of a Family Man" from 1919. Moving and chatting all by itself, Kafka's spool presents itself as a puzzling enigma for the reader as well as the narrator who simply cannot figure out what kind of being this lively thing is: a diminutive human of wood or a somewhat untraditional tool? Jane Bennett, however, is less in doubt. In Vibrant Matter (2010) she utilizes Kafka's story and its non-human protagonist for making present and tangible her ontological concept of vital materiality. Here, the not-quite-dead and not-quite-living spool becomes a speculative figure for imagining what life beyond anthropocentric dichotomies between "dull matter (it, things) and vibrant life (us, beings)" might look and feel like (Skiveren 2018)

If this is to be our starting point, then we might be in trouble already. Firstly, there seems to be a logical error in play here: Odradek's weird status stems not from some sort of a split nature- "not-quite-dead and not-quite-living" - but from ours, the observers', own uncertainty as to what this nature is. He's not part-person, part-object; it's just that the reader doesn't know-indeed, has no means of knowing — whether he's more of a person or an object.

Secondly, although Odradek's nature might indeed be puzzling "for the reader as well as the narrator," it is puzzling for the reader precisely because it is puzzling for the narrator; Odradek exists only as a writer's invention, mediated through an account of another of his inventions (the narrator). Indeed, accounting for the nature of Kafka's typical narrators - unreliable, lost, thrown into unusual situations and detached from the world around them-one could even suggest that what's puzzling in The Cares of a Family Man is the mental condition of its protagonist, rather than the ontological status of the object of his gaze.

And, finally, even if we leave all these doubts aside and assume that Odradek really is an essentially "nonhuman" protagonist, an item come to life-we should still ask whether this is as "enigmatic" a scenario as both Bennett and Skiveren would have us believe. After all, conventionand genre-wise, what Kafka offers his readers is just a spin on literary anthropomorphism: the indisputable weirdness that seems to distinguish Odradek from Frosty the Snowman or Cogsworth is the result of Kafka's narrative technique rather than a simple byproduct of Odradek's own features. In other words, we should ask - at risk of sounding somewhat naïve-whether our ability to imagine non-human actors can be seen 
as a proof, specifically as a proof that such non-human actors exist outside of our imagination. Both Bennett and Skiveren seem very eager to assume that it can; this is not only a somewhat simplified view of fiction in general, but it also risks ignoring the nature of literature and art as an essentially inventive and unpredictable practice. If Odradek is a description of an ontological discovery, rather than an invention of Kafka's own imagination (which, in itself, is a product of all the material interactions that shaped it), then agency suddenly seems like a zero-sum game: the agency of the "vibrant matter" comes at the cost of diminishing the agency of an author, and, in turn, makes literature itself seem more deterministic.

To an extent, this issue may stem from an apparent discursive reversal of the argument. Instead of using Odradek as an illustration for a certain otherwise established concept, a way of adding nuance and complexity to an existing narrative, both Skiveren and Bennett use Kafka's story as a starting point-as if Odradek's fictional existence pointed out the existence of a corresponding non-fictional being (or a type of matter). This mode of writing-one where the lines between the anecdotal and the analytical, a dramatisation and an interpretation, are not so much transcended or abolished as they are intentionally blurred-is, unfortunately, quite common in new materialist writing.

Nonetheless, Skiveren understands some of the difficulties inherent in any project of a new materialist literary criticism:

At first sight, though, literature does not seem to be the most obvious alliance for such projects. How, we might ask, does one align the renewed emphasis on the non-human agency of materiality, biology, and nature emblematic of new materialism with a phenomenon that is traditionally associated with a wholly different domain, namely the all-too-human character of discourse, textuality, and semiotics? (Skiveren 2018)

What's peculiar about this otherwise sober observation is the framing of the issue in terms of a "tradition" existing, one can assume, within literary studies. "Traditionally" literature and the study of literature are apparently solely interested in the matters of "discourse, textuality and semiotics." Moreover, these traditional associations constitute "a wholly different domain" from the ones put forward by the new materialists. This implicit division, the act of separation that seems to lie at the very foundation of a new materialist literary criticism, will become quite important later on; for now, Skiveren notes that 
This challenge is, of course, not an easy one. But one way to bridge the gap, it seems, has been to recast literature as a material force that exceeds the domain of the Anthropos by resisting the epistemological inspections of the reader. No longer simply a discursive site for negotiating more or less subversive identity constructs, literature becomes an abstruse and recalcitrant non-human actor that can never be fully known. (Skiveren 2018)

This understanding of literature's material nature is based on the empirical observation that our best efforts to grasp the totality of a work's meaning almost never succeed — there is always something left to be said about the text, and the interpretation (as deconstruction as well as countless post-structuralist thinkers taught is) is seemingly never complete. It's not hard to understand how some may be tempted to see this remainder as inherently more "material"; we tend to associate resistance with materiality. One could go as far as to say that, from this perspective, the very possibility of the reader's mistake, as well as the imperfect nature of every paraphrase, are both in themselves a hard proof of the text's materiality, and as such they also — and this is arguably more important-serve to sever the link between literature and its "traditional associations" with "discourse, textuality and semiotics."

Although Skiveren points out that certain new materialist thinkersincluding Bennett, but also Stacy Alaimo and Mayra Rivera— "construe literature as a privileged site for affectively and imaginatively exploring the world of material forces" (Skiveren 2018), it seems that at this point we should clearly distinguish between any project of a new materialist literary criticism (or theory) and a more general interest in literature as a way of "cultivating more matter-attuned and fine-grained sensibilities" (Skiveren 2018). If the new materialists have indeed, as Beetz points out, devoted little time to the issues of "the fundamental materiality of language and discourse," then this might explain why there have been few attempts at demonstrating, in practical terms, what a "new materialist" mode of reading and criticism could look like. It seems that many authors are more interested in seeking out textual illustrations for certain new materialist concepts, rather than reading texts in a new materialist "way," whatever this could mean. This approach may be ultimately quite misleading. For instance, in the recent anthology Material Ecocriticism (Iovino \& Oppermann 2014), which seeks to establish a link between new materialisms and the practice of ecocriticism, all four essays included in the section "Poetics of Matter" seem focused on seeking out the works of art that specifically illustrate certain concepts crucial to the new materialist thought and sensitivity; in other words, rather than 
sketch out a new materialist mode or way of reading, they invoke these works in order to prove that certain general philosophical intuitions are shared by a larger group of people, some of them artists or writers. These readings, however inspiring and productive they might prove on a case-to-case basis, tell us little about a new materialist approach to literature or text as such. It might very well be, for instance, that Walt Whitman (or Wallace Stevens, to mention just two authors eagerly referenced in the new materialist circles) shares, at least in his more ecstatic moments, a certain general view of the world with Jane Bennett or Gilles Deleuze. This, however, neither requires the critic to call on a new set of theoretical tools (indeed, in this particular case all four essays are quite traditionally hermeneutic), nor tells us anything about the practice of new materialist literary criticism. This tendency is obviously neither new, in the context of modern literary studies, nor particularly harmful in and of itself; it just seems important to distinguish such an approach from any serious attempt at founding a "new materialist" mode of literary criticism.

Another approach to literary studies that may share some of the new materialist sensitivity but mustnonetheless be sharply distinguished from any possible new materialist criticism, focuses on the empirical observation that readers tend to ascribe agency to certain fictional characters or beings, and uses various sociological and psychological tools in order to explain that phenomenon or its social consequences. This approach combines sociology of reading and reception, evolutionary psychology and neuroaesthetics - to name just a few disciplines - in order to research and explain our reactions to text, rather than establish a new mode of interpretation. ${ }^{1}$

\section{Popeye, or the Search for Materiality}

Skiveren's summary is telling in its intuitions; it creates an impression that, for the new materialists, the "true" materiality is mainly to be found in the domain of the non-human, and so the material side of any text consists primarily in things that are independent of the author, their style, their intention and their technique. One can sometimes see this

1 An excellent example of such an approach is Blakey Vermeule's Why Do We Care About Literary Characters? (2010), which, as demonstrated by Jennifer Ashton (2011) not only avoids many of the traps associated with post-humanist literary criticism and the affective turn, but seems entirely compatible with the „strong” intentionalism as sketched out by Walter Benn Michaels. 
sentiment surface seemingly unintentionally, as in the preface to Serenella Iovino's and Serpil Oppermann's anthology of essays on materialist ecocriticism:

Agency assumes many forms, all of which are characterized by an important feature: they are material, and the meanings they produce influence in various ways the existence of both human and nonhuman natures. Agency, therefore, is not to be necessarily and exclusively associated with human beings and with human intentionality, but it is a pervasive and inbuilt property of matter, as part and parcel of its generative dynamism. From this dynamism, reality emerges as an intertwined flux of material and discursive forces, rather than as complex of hierarchically organized individual players. (Iovino \& Oppermann 2014, 3)

Resisting the emphasis on linguistic constructions of the world, formulated by some trends of postmodern thought, the new materialist paradigm is premised on the integral ways of thinking language and reality, meaning and matter together. A key point, provided by Karen Barad's theory of agential realism, is that phenomena result from the intra-actions of material and discursive practices and agencies, which co-emerge at once (hence intra-and not inter-action), thus constituting the world "in its ongoing becoming." Matter and meaning, Barad states, are "inextricably fused together, and no event, no matter how energetic, can tear them asunder. . . Mattering is simultaneously a matter of substance and significance" (...) In other words, the borders between meaning and matter are constitutionally porous, making the "intimate" material-semiotic connection between the "inside" and "outside" of organisms recognizable at smaller as well as larger levels of organization. (Iovino \& Oppermann 2014, 4)

The emerging dynamics of matter and meaning, body and identity, being and knowing, nature and culture, bios and society are therefore to be examined and thought not in isolation from each other, but through one another, matter being an ongoing process of embodiment that involves and mutually determines cognitions, social constructions, scientific practices, and ethical attitude (Iovino \& Oppermann 2014, 5)

If ecocriticism has a grounding assumption at its origin, it is the tight connection between literature and the natural-cultural dynamics of the material world. (Iovino \& Oppermann 2014, 6) 
Saying that literature is "tightly connected" to the "dynamics of the material world" is obviously vastly different from saying that literature itself is a material construct. Similarly, phrases like ,an intertwined flux of material and discursive forces," „inextricable fusion” of matter and meaning, „integral ways of thinking language and reality,” „borders between meaning and matter” that are „constitutionally porous” etc. all suggest that meaning-language in its specifically semantic aspectremains closely linked to the material world, but is not in itself a proper part of this world. Although Iovino and Oppermann immediately attempt to shift focus to how closely and inextricably these two spheres are tied together, what's more important from the materialist perspective is this strong assertion of fundamental (even if purely analytical) difference.

The purpose of this assertion is to emphasise the sheer force of materiality present in the natural world, especially in its non-human actors and spaces. Considering Iovino and Oppermann see their project as a part of the „material turn” (Iovino \& Oppermann 2014, 2), and seem to believe that whereas the materiality of the text has been largely ignored within literary studies, the text's meaning has traditionally been a privileged category within literary criticism, what emerges is a picture of the relationship between meaning and matter as a zero-sum game: the more we focus on the text's actual materiality-understood now in terms of non-human agency, and the link between text and nature- the less we can focus on its meaning.

Eileen Joy, who, in her search for a new mode of reading, reaches out to both new materialisms (e.g. the work of Jane Bennett) and speculative realism (including Graham Harman's object-oriented ontology), also instinctively identifies the material aspects of the text with its non-semantic and non-authorial side, as if its "proper” materiality could only be found outside all the activities traditionally associated with interpretation:

And the idea might then be, not to necessarily make sense of a literary text and its figures (human and otherwise) - to humanistically re-boot the narrative by always referring it to the (always human-centered) Real (context, historical or otherwise, for example, or human psychology)—but to better render the chatter and noise, the movements and operations, the signals and transmissions, the appearances and disappearances of the weird worlds, and their figures, that are compressed in books (a different sort of realism that always exceeds the intentions of authors and readers, and thanks to language's errant-deconstructive tendencies, cannot be fully captured in the nets of our semantics only), and to see 
better how these teeming pseudo-worlds are part of my brain already, hard-wired into the black box of a kind of co-implicate, enworlded inter-subject-object-ivity in which it is difficult and challenging to trace the edges between self and Other, between the Real and the fabulated. (Joy 2013, 31)

In this single (!) sentence Joy clearly establishes a link between what she calls the „weird” reading and the various modes of reading interested in such notions as context, history, "the Real” or the intentions of human actors (authors and readers). Although one could argue that "the chatter and noise," "the appearances and disappearances of the weird worlds" may very well be present in the text because of its author's intention, as a part of its meaning (as is the case with that old Speculative Realist favourite, H. P. Lovecraft), Joy locates all these elements firmly and explicitly outside „our semantics”. Thus her „weird reading” must be clearly distinguished from simply reading ,for" weirdness, i.e. reading that is particularly interested in the intentional moments of weirdness within the text. Joy links this project to Jane Bennett's notion of ,vibrant matter," as well as a vaguely Spinozian perspective:

Yet, narratives also contain discrete, disconnected instances of being and becoming that are always attempting to expand beyond or subvert the larger narrative system - these instances, or "units" (as Ian Bogost would term them) are like things, material elements with their own conatus (Spinoza's term for any thing's tendency to persist in existing), which always leaves the system open to a creative and possibly fruitful chaos (a plenitude of generative unruliness whose historical tense would be the future perfect subjunctive: what would have been, or, what would have not been). (Joy 2013, 29)

These instances are precisely the "chatter and noise” on which Joy seeks to found her „weird reading." Although she does not explicitly deny the materiality of, say, the communicative function of literatureto do that would be indeed quite provocative, even by the new materialist standards - still, by emphasising the status of "chatter and noise” as material things, she strongly suggests (just like Iovino and Oppermann) that it's they who constitute the "properly" or "truly" material side of the text. While a simple „reading for weirdness" would make no assumptions about the ontological status of this or that element of narrative, "weird reading" seems entirely based on the assumption that certain aspects of a work of literature are if not more material, than at least material in a fundamentally different manner than all others.

Levi R. Bryant, a speculative realist philosopher who's often commented on Joy's ideas, seems to recognise the fundamental issue with 
this approach, at least on a theoretical level, although he does not link it directly to Joy's work. He opens his commentary on Joy's lecture with these remarks:

One of the things that I've found most stunning, that in certain ways I somewhat regret, is my claim that fictions are real. Now there's something about me that seems to create a ruckus wherever I go- and that's been above all true of my pronouncements on this blog -but there have been few things I've said that have generated more heat than this thesis. Now for any materialist I would think this thesis would be obvious. If you're a materialist then you're committed to the thesis that all things are, well, either material or void. Fictions aren't void, so that entails only one option: they're material. (Bryant 2011a)

Bryant begins with a clear assertion that fictions - which seem to stand here for texts in general - are material as a whole, by default. He thus seems to avoid a fundamental split between the meaning and matter, on which both Joy's „weird reading” and Iovino and Oppermann's „material” ecocriticism are founded. Unfortunately, he quickly veers into the familiar territory:

For years, along these lines, my mantra has been that texts aren't simply about something, they are something. In other words, texts should not simply be understood in their referential and modal dimension, but should also be understood in their sheer materiality as entities, like animals, humans, rocks, and neutrinos, that circulate throughout the world. This is at the center of what I mean when I say that fictions are real. I am not making the claim that there is a person that exists like a human, named Popeye that I could marry, that has amazing biceps, that grows stronger when he eats his spinach, etc. No, I am making what I believe to be the obvious and common sense thesis that the cartoon Popeye ought not simply be understood as what it is about (its referential dimension), but also in terms of what it is (a material entity circulating about the world). (Bryant 2011a)

As soon as Bryant makes a seemingly innocent observation that "texts aren't simply about something, they are something," he enters the path that eventually leads him back to a fundamental split between the material and non-material aspects of texts. If what makes texts material is their “being," rather than their being „about” something, then they are only material in spite of the latter. Their existence as "material entities” is then opposed to their "referential dimension” which, consequently, appears as essentially non-material. Although Bryant eagerly concedes to fictions their material nature, he then confines it solely to one aspect 
of their being - that which he sees as traditionally omitted by those modes of criticism that focus on the meaning of texts. Meaning and matter are thus again pitted against each other. Indeed, one can imagine that the split between referential and material may be just the first step in a potentially infinite series of similar division: because, to put it bluntly, why should one stop here, at this arbitrary level, just below the surface of the text's totality? Surely there are things - that is to say, forces and processes of a social, cultural and economic nature-that, although linked to the text's "circulation," remain less material than the others; say, the physical transport of books, as compared to a mere conversation among their readers? And even then, one can imagine that some copies of said books can be seen as more material than others-are paperbacks, for instance, more „material” than ebooks? What about audiobooks — are the ones sold on tape more "material” than the ones distributed digitally?

All these questions stem, of course, from a set of inherently non-materialist assumptions; and absurd though they may seem, they all follow logically from the initial split between the texts' „referential” and material sides. This split is, in fact, in clear contradiction with Bryant's own initial remark that a materialist remains „committed to the thesis that all things are, well, either material or void." What is it that would make this thesis applicable to a fiction as a whole, but not to all of its dimensions? In other words, why is its „referential dimension” exempt from this fundamental rule? Doesn't it follow, from Bryant's own assumptions, that both the text's „,being” and it's „being about something” are „either material or void”? In other words, mustn't the meaning itself be „either material or void"?

In a sense, Bryant's approach is not unlike the never-ending search for the fundamental particle in philosophy or physics: where the very possibility of a further division pushes the moment of discovery of the true foundation of our material reality further away. Whereas Jameson and other historical materialist thinkers suggest that we can only assume a materialist perspective, Bryant (as well as Joy, Iovino and Oppermann) are all on the lookout for the source of the matter's (and text's) own materiality.

This, obviously, puts the whole idea of a „material turn” in literary criticism in a very precarious position. We either embark on a never-ending search for the „truly” material elements of the text—which will not only inevitably lead to predictable arguments over which thinkers and critics are more materialist than the others, but which also immediately gives an astonishing amount of ground to those who would like 
to see literature as the domain of pure ideas-or we accept that the object of a meaning-focused analysis is in no way less material than that of a potential new materialist criticism; but then the latter's own reason for existence more or less vanishes. We can obviously sympathise with some of Bryant's (and Joy's) apparent political goals: their desire to make literary criticism more inclusive, egalitarian, democratic etc. But ultimately, if we follow Jameson's intuitions, these „new” materialist approaches serve only to reinforce the old idealist cliché, namely, that the discursive, the intellectual or the textual dimensions of a work of art are somehow less „material” than things like print, paint or canvas.

This is by no means to say that a sincere interest in Marxism may magically prevent anyone from making mistakes similar to those of Joy and Bryant. A good example is Imre Szeman's Introduction: a Manifesto for Materialism from 1999. Szemen, although ostensibly sharing many of the intuitions that gave birth to the "material turn," remains committed to a certain heterodox line of historical materialist thinking. He writes his manifesto with an explicit goal of including in the critical practice - particularly in reference to Canadian literature and criticismthings that have historically been „left out” and forgotten, due to the critics' apparent lack of focus and consequence in the matters of matter and materiality. Like myself, Szemen starts with Jameson's remarks on the inherently polemic nature of materialism, and-wary of the fact that "while there may be numerous materialisms in name, few are materialist in spirit" (Szeman 1999, 4) - is initially careful not to turn an essentially negative approach into yet another positive method: „If materialist criticism is thus often concerned with matter, the materiality of social and cultural forces, and with political economy, it is not just because it is "materialist» but also because these are the elements most commonly "left out» of typical examinations of cultural objects, especially in the case of literary texts" (Szemen 1999, 6). His project of materialist criticism, it seems, will remind us about the essentially material nature of every aspect of the text, rather than try and point out then elevate its „truly” or „particularly” material elements.

But unfortunately Szemen soon follows in the steps of Joy and Bryant, albeit for a slightly different reason. Following Régis Debray, who famously criticised Marxism for not examining closely „the connections between text and world", Szemen proposes a renewed focus on the „material” (as in „physical”) production of the texts (meaning mainly texts-as-objects, or vehicles), as well as the institutional framework that makes this production possible. Although a focus on these largely political and socioeconomic issues may seem to reinforce the materialist 
The reason is clear: a self-proclaimed materialist critic will seek to emphasise the material nature of the text, which they can do only by elevating some of its aspects above the others. The only other way to imagine materialist criticism would be to see its task-at least when it comes to reading and interpreting - solely in terms of restoring a "natural”

balance, regaining a way of perceiving the text which is not only material but also, and as importantly, default. In other words, it would once again be a polemic stance rather than

a method-a stance that consciously limits itself to revealing and refuting various forms of idealism, rather than "inventing" anything

new.

nature of his project, Szemen finally succumbs to the idea of this supporting apparatus being the only truly material force, as opposed to the „intellectual” sphere, which includes things such as concepts, discussions, but also „bookish common knowledge” and — presumably_meanings (Szemen 1999, 10).

Without going into further detail, what Szemen's manifesto proves is that a division of the kind we see in Joy's and Bryant's work is a necessary consequence of seeing any project of "materialist literary criticism” in terms of a method. Although understandable on a practical level— in the contemporary humanities establishing a new method or a new turn may seem not only the best, but the default way of asserting one's autonomy and position - an attempt at inventing a materialist method of reading and interpreting texts seemingly always results in a split between an imagined "material” side of of the text and its non-material counterpart. The reason is clear: a self-proclaimed materialist critic will seek to emphasise the material nature of the text, which they can do only by elevating some of its aspects above the others. The only other way to imagine materialist criticism would be to see its task-at least when it comes to reading and interpreting - solely in terms of restoring a "natural" balance, regaining a way of perceiving the text which is not only material but also, and as importantly, default. In other words, it would once again be a polemic stance rather than a method-a stance that consciously limits itself to revealing and refuting various forms of idealism, rather than ,inventing” anything new. It seems, however, that the very idea of a "natural" way of reading would be anathema to many contemporary critics, including those associated with new materialisms.

\section{4. Überbau, or on Genuine Materialism}

In more ways than one, the split at the heart of the new materialist literary criticism resembles the well-known Marxist division between Basis/Grundlage and Überbau, the base and the superstructure. Or, should we say more precisely, it resembles what many non-Marxists believe to be the Marxist version of this divide: a fundamental split between the socioeconomic "foundation" of all social reality and a nigh superfluous cultural "supplement" that's almost entirely dependent on the former.

This is obviously a well-known and oft-discussed issue that has resurfaced numerous times throughout historical materialism's relatively short history and even today it can be approached from many different angles. 
For my part, in the context of this essay, I believe a brief discussion between David Graeber and Richard Seymour that took place over a decade ago might prove particularly instructive.

In Turning Modes of Production Inside Out (2006), Graeber set out to criticise the notion of the "mode of production" in what he saw as its traditional Marxist sense, in order to offer a new understanding of this category — one that would be rooted more firmly in the world of everyday human interactions, "processes by which people create and shape one another":

The question then becomes: what would a 'mode of production' be like if we started from this Marx, rather than, say, the Marx of the Contribution to a Critique of Political Economy? If non-capitalist modes of production are not ultimately about the production of wealth but of people—or, as Marx emphasizes, of certain specific kinds of people - then it's pretty clear that existing approaches have taken entirely the wrong track. Should we not be examining relations of service, domestic arrangements, educational practices, at least as much as the disposition of wheat harvests and the flow of trade?

I would go even further. What has passed for 'materialism' in traditional Marxism-the division between material 'infrastructure' and ideal 'superstructure'-is itself a perverse form of idealism. Granted, those who practice law, or music, or religion, or finance, or social theory, always do tend to claim that they are dealing with something higher, more abstract, than those who plant onions, blow glass or operate sewing machines. But it's not really true. The actions involved in the production of law, poetry, etc., are just as material as any others. Once you acknowledge the simple dialectical point that what we take to be self-identical objects are really processes of action, then it becomes pretty obvious that such actions are always (a) motivated by meanings (ideas) and (b) always proceed through a concrete medium (material), and that while all systems of domination seem to propose that ' $\mathrm{No}$, this is not true, really there is some pure domain of law, or truth, or grace, or theory, or finance capital, that floats above it all', such claims are, to use an appropriately earthy metaphor, bullshit.

(...)

A genuine materialism, then, would not simply privilege a 'material' sphere over an ideal one. It would begin by acknowledging that no such ideal sphere actually exists. This, in turn, would make it possible to stop focusing so obsessively on the production of material objects - discrete, selfidentical things that one can own - and start the more difficult work of trying to understand the (equally material) processes by which people create and shape one another. (Graeber 2006, 70-71) 
Graeber's criticism seems truly on point, in that it touches on a way of thinking, or an ideology, that seems prevalent in capitalism and on which, as he rightly points out, all systems of domination seem to at least partly rely. In his attempt to distinguish „genuine” materialism from what may be seen as idealism in reverse (distinguished as historical materialism), he's even careful not to speak of the dialectical unity of "meaning" and "matter" — so this idealist opposition is not reintroduced by accident-but rather of the unity of „meaning” and „material”, or „medium”.

The only major issue with Graeber's argument is that its nominal target seems somewhat ill-defined. His idea of "genuine materialism” is surprisingly close to that of non-Stalinist marxists; Richard Seymour was quick to point this out on his blog:

This is a lucid passage, and also a very frustrating one. It is lucid about the fetishism of ruling class ideology, and frustrating in how it represents its supposed foil. To begin with, it is unclear what is meant by „traditional Marxism.” Suffice to say that it wouldn't include E. M. Wood, E. P. Thompson, Alasdair Macintyre, or any number of anti-Stalinist marxists who have problematised the idea of a base-superstructure dichotomy, either rejecting the whole metaphor, or maintaining that conceiving it as a dichotomy is contrary to Marx's original intention. These arguments were often directed against a highly mechanical and scholastic interpretation of Marx that was popularised by the Soviet Union and its supporters, the purpose of which was to rationalise Stalinist accumulation methods. The logic of the Stalinists was that if the superstructure is determined by the economic base then we must only develop the means of production and the political superstructure of socialism is sure to follow. So it is possible that by „traditional Marxism,” Graeber actually means Stalinist vulgarisation. Or it could just be another sock-puppet-as-protagonist, cf. „standard leftist,” „typical PC liberal," etc.

That Marx himself does not intend the base-superstructure metaphor as a dichotomy is clear in the Preface to A Contribution to the Critique of Political Economy, the text which Graeber finds particularly problematic (as opposed to, eg, The German Ideology)

(...)

$[\mathrm{N}]$ owhere does Marx suggest that the superstructure is ideal, or that there is actually an „ideal sphere” distinct from material activity. In fact, Marx's position on this is remarkably similar to that of Graeber. Marx, and I suspect most marxists, would not be scandalised by the assertion that the actions which produce law and poetry are themselves material. The thrust of the quoted passage from the ,Preface', as I read it, is not that material processes produce 
a separate, ideal superstructure. It is that what is referred to as superstructural is in fact a material process-more specifically, a process brought about by human activity. It is, in other words, precisely to reject the reification of social processes and their transformation into autonomous entities that dominate life in an almost god-like fashion. (Seymour 2010)

Graeber's „genuine” materialism is in fact, as Seymour points out, at its foundation basically identical with historical materialism as it appears outside of a „vulgarised” Stalinist framework. It remains based on two basic tenets or observations. First, its insistence on defining things like „superstructure” in terms of processes rather than reified objects (here, new materialisms, with their rhetoric of change and fluidity and porous borders, may seem like historical materialism's natural ally). But more importantly, this version of materialism rejects the very idea of the base/superstructure division as an instrument for defining the "truly" material side of reality. Both the base and the superstructure are produced through a material activity; indeed, the very possibility of thinking them separately, the idea of base and superstructure as distinct spheres, is no more or less material than anything else. The meaning and the medium are both equally "material”; or, rather, they are simply both material, because the word "equally" assumes that things may be material in different proportions, thus opening up a way for the new materialist split to be brought back. To put this whole issue back in the context of literary criticism: texts are either material or void, but so is the meaning itself and, indeed, everything else about them. A materialist "method" that does not understand this can be only idealism in reverse.

Graeber and Seymour seem to follow, at least in spirit, many of the remarks offered by Maurice Godelier in his seminal The Mental and the Material: Thought Economy and Society (Godelier 1986). In both cases, what's at stake is not only a certain notion of materialism as a practice, but also a renewed appreciation of „superstructure” as an equally material part of our shared reality and lived experience:

Thus it is by abstraction that thought may separate the various parts of a whole, the productive forces from the relations of production, and divide these two realities (thenceforth habitually called the infrastructure') from the remainder of social relations (which then become, superstructures'). In passing, it is worth noting that ,infrastructure' and, superstructures' are very poor translations of Grundlage and Überbau, the terms actually used by Marx. The Überbau is a construction, an edifice which rises up on foundations, Grundlage; and it is a house 
we live in, not the foundations. So another translation of Marx, far from reducing the superstructures to an impoverished reality, could have emphasized their importance. (Godelier 1986, 6-7)

If the idea of a „material turn” seemed doubtful before, now we have an even clearer reason to treat it with suspicion and even scepticism. Of

And so it seems that the material turn is not a very materialist term after all. course, the vague metaphor of a „turn” can be reinterpreted and reused in countless ways, so no doubt there will be those who understand the material turn simply in terms of reminding ourselves of the „forgotten or repressed" materiality of certain parts of our lived experience, social or otherwise. But for many others, a "material turn” seems to imply that we need a new method, or a new research field or a new theory, in order to revive materialism or-even worse-in order to live more „material” lives. The latter is obviously never the case-as it would imply that we can also truly escape the material world, a skill that even tenured professors of literature do not seem to possess-while the former, i.e. the idea that we need a new set of theoretical tools to „revive” materialist criticism, seems at least doubtful: if materialist criticism is just a polemic stance, if at the end of the day everything is a product of material activity, what's needed is consequence in pointing that fact out, rather than the safety of an established method. And so it seems that the material turn is not a very materialist term after all.

\section{Toad-rock, or a Reenchantment}

Of course, a general criticism of new materialisms as such-as a philosophy or a discursive practice, so to speak, rather than a specific approach to literature and interpretation-has been articulated by some very prominent Marxists, including Terry Eagleton (2016) and Slavoj Žižek (2014). The former is particularly explicit in his criticism of new materialisms' totemic or fetishistic vision of the world (,it is essentially a pagan vision" [Eagleton 2016, 10]), in particular its vision of matter, which seems to reproduce the fetishism typical to post-structuralism as the direct predecessor of new materialisms („where thinkers like Jacques Derrida say 'text,' new materialists say 'matter.' Otherwise, not much has changed" [Eagleton 2016, 11]). All of this culminates in what Eagleton sees as a hasty downplaying of humanity's agency; new materialists end up „with the kind of contemplative vision of the world that (...) Marx criticises in Feuerbach" (Eagleton 2016, 13).

Eagleton offers some well-articulated and politically crucial criticism 
of the new materialisms; however, his arguments rely on a broad consensus as to the idea of alienation, i.e. a general recognition that alienation exists and remains (at least by default and is most cases) something that we should fight and resist rather than embrace; that it is first and foremost a weapon of capital rather than a tool for universal emancipation. Meanwhile, such a consensus is hardly a given among the new materialists. In New Materialisms: Ontology, Agency, and Politics (Coole \& Frost 2010) —an anthology that serves if not as a source document for the new materialist movement, then at least as a focal point of sorts-Jason Edwards directly attacks Henri Lefebvre for his attachment to the very idea of alienation, seeing it as one of the most "problematic” moments of the philosopher's work (Edwards 2010, 291). Elsewhere, the proponents of material ecocriticism openly call it „a story-laden mode of reenchantment." (Cohen 2014, x). They seem to fear neither the fetishistic (or totemic, or „pagan”) vision of the world offered by the new materialisms, nor the danger of it being weaponised by capital.

The importance of Eagleton's criticism, which we could probably see as the model Marxist criticism of new materialisms in general, cannot be overstated; it seems politically urgent and hugely important, and it will no doubt speak to at least some of those involved in the new materialist project. But short of assuming that those unconvinced are not worth debating, it seems almost equally important for historical materialists to develop a line of criticism that would point out various contradictions within the new materialists' own framework-and seek to persuade them on their own terms, so to speak.

One such argument-indeed, one that seems already prevalent among the critics of new materialisms, although it arguably has its roots in some criticisms of the Agent-Network theory- would start with the very notion of non-human agency. The empirical and experiential foundation of the idea of agency, this argument would go, is our own subjectivity, either individual or collective; by default, we imagine agency in terms of something that we (as humans, or people, or whatever other collective noun we may think of to call ourselves) possess. That's why our understanding of agency has changed throughout history, but that is also why we tend to measure the agency of non-human actors (such as animals) in terms of the similarities they share with us. Because our understanding of our own agency is neither universal nor ahistorical, there is some urgent political criticism to be made here as well. For instance, one could argue (and indeed many do) that we can hardly imagine our own agency_or ourselves as actors - in terms other than that of contract and/or casting a vote, and we should try and come up 
with a radically different notion of our own agency. But this is hardly the same as a philosophical call for expanding our understanding of agency so that it may include rocks, cars and chairs. Such a call requires much more than anecdotal evidence and concepts borrowed from quantum physics - namely, it needs to be based on a clear explanation of the passage between our everyday experience, our understanding of agency as it already appears in our daily lives (and our politics), and the new theoretical proposition. Otherwise, it amounts to little more than a straightforward demand that we abandon our own lived experience and suspend our empirical knowledge through a sheer act of will, motivated by a vaguely progressive political intuition. Such a demand would obviously go against the basic tenets of any materialism. But the new materialists seem strangely averse to any attempts at describing this passage; indeed, one could be excused for seeing it as almost intentionally blurred.

Another, similar argument that would seek to productively criticise new materialisms on their own terms would question the space that a projected new materialist reader/interpreter seems to occupy in relation to the material aspects of a text. (The peculiarity of this position was already signalled by the fact that it allows us to perceive the text as split between the material and the non-material, as if we could observe this division from the outside.) Again, this line of criticism would question our ability to simply „step outside” of certain elements of our material experience. Take, for instance, those points or moments in the text whose meaning seems to elude us. New materialists call on us to actively appreciate these points not as moments of particular semantic density, so to speak, where we need to make an exceptional effort at interpreting and ultimately understanding the text, but as moments that we need to appreciate precisely in and for their apparent incomprehensibility. For Eileen Joy, for instance, the idea of „weird reading” is based on appreciating such moments for what they are:

\footnotetext{
Nevertheless, works of literature are also unique events that possess a penumbra of effects that can never be fully rationalized nor instrumentalized, and there is no one set of relations within which the whole range of any one text's possible effects can be fully plumbed or measured. There is always something left over, some remainder, or some non-responsive item, that has to be left to the side of any schematic critique, and this is an occasion for every text's becoming-otherwise. (Joy 2013, 29)
}

It bears no argument that such „remainders” exist, i.e. that there are 
many things in many works of literature that we can safely assume we'll never fully understand (either personally or even collectively, as „humanity”). What's potentially problematic is whether we can derive any practical conclusions from this fact. If we were to practice „weird reading, "for instance, we would need to appreciate these moments for what they are, or even work to preserve them; anything else would mean working actively against the material weirdness of the text. This means the best we can do is wilful ignorance; trying not to think too hard of the things we haven't yet understood. Even if we set aside the potential ethical and political implications of such a project, the question is: can such a state of wilful ignorance be achieved in practice?

And if we were to follow Bryant's advice, and focus on what the fictions are as well as what they are about, could we really do the former without constantly referring to our own understanding of a given fiction's meaning? In other words, if we have a certain idea of who Popeye is within the original work of fiction, can we accept that he is as much Popeye as someone else's interpretation of the same character?

One can already sense in these questions a possible connection to some of the arguments and observations historically discussed within the pragmatist tradition. But before we establish such a connection (and introduce a couple of fresh names and concepts), let's have a look at the very first paragraph of Jeffrey Jerome Cohen's foreword to Iovino and Oppermann's anthology:

A rock jumps. Every hiker has had the experience. The quiet woods or sweep of desert is empty and still when a snake that seemed a twig writhes, a skink that was bark scurries, leaves wriggle with insectile activity. This world coming to animal life reveals the elemental vibrancy already within green pine, arid sand, vagrant mist, and plodding hiker alike. When a toad that seemed a stone leaps into unexpected vivacity, its lively arc hints that rocks and toads share animacy, even if their movements unfold across vastly different temporalities. Just as the flitting hummingbird judges hiker and toad lithic in their stillness, a rock is within its properly geologic duration a wayfarer, a holder of stories of mountains that undulate and continents that journey the sea. The stone-like toad discloses its intimacy to toad-like stone. Both are part of a material world that challenges the organic bias of the adjective "alive." (Cohen 2014, ix)

New materialists seem to often privilege such anecdotal, pictorial moments in various ways; to use the new materialisms' own rhetoric, these are the moments of local indeterminacy, surprising meetings, unexpected intra-actions from which both the object and the subject trace 
their roots. Here, a moment when a rock seemingly „transforms” into a toad is privileged from an epistemological point of view: it reveals something crucial about the nature of the world, the flows and ties that define our shared material reality.

But no such privilege is extended to the moment directly after that moment of surprise, that is, the moment when we realise that what happened was not a wondrous case of a pebble come to life, or an equally wondrous spontaneous transformation of a rock into an animal, but, in fact, a case of bad vision, a simple mistake. This epistemological moment is seemingly deprived of any material viability or legitimacy; indeed, it is not even spoken of. But isn't it the necessary conclusion to every such scenario: confronted with a shocking event, we try to explain (and this process is as much a part of our everyday material lives as anything else) what just happened and, provided the explanation is sufficiently satisfying, we get over our initial shock? For a split-second, we might have thought that rocks were indeed able to jump; but now that we know what really happened, it's not that we think the rock can no longer jump - we know that it could never have jumped in the first place. The sense of wonder is gone-or if it's still there, its reason is now altogether different.

Cohen calls on us to actively maintain the special status ascribed to the initial moment of surprise, to regain and maintain our own sense of wonder. But this would require us to cut out from our own experience another moment, the moment of realisation. In order to truly appreciate the material world, it seems, we need to forget what we otherwise know-this is what the new materialisms demand of us. This is also where the new materialisms in general, the new materialist literary criticism in particular, and the idea of „story-laden reenchantment” come together: in the call to stand outside of our own lived experience. Hardly, one could say, a materialist proposition.

\section{Michaels, or a Polemic Stance Once Again}

There is, I believe, an approach to literary criticism that both solves the fundamental issues found in the new materialist project and opens up a way of thinking about literary criticism in a truly materialist-and yet very inclusive-manner. This approach, fundamentally anti-theoretical and anti-methodical, is sometimes known as the „strong” intentionalism²,

2 In the original essay, Michaels and Knapp use the name „intentionalism” 
and is associated primarily with the work of Walter Benn Michaels. It was established in the early 1980s by Michaels and Steven Knapp in a series of articles, the most well-known of which remains Against Theory (Knapp \& Michaels 1982). These articles have since served as a foundation for an anti-capitalist and, specifically, anti-neoliberal project of political and cultural criticism, developed by Michaels in books such as The Shape of the Signifier (2004), The Trouble with Diversity (2006) and, most recently, the photography-focused The Beauty of a Social Problem (2015).

Against Theory, as well as Michaels' work in general, is at the same time well-known and often misunderstood. Thus a brief reconstruction of the relevant parts of his argument seems in order.

On an institutional level, Michaels' (and Knapp's) writings sought to abolish literary theory as a field or a branch of studies — or, to be more precise, they aimed to reveal the fundamental impossibility of „theorising" things such as meaning and interpretation. There can be no theory of meaning, Michaels and Knapp said, because there can be no such "general account" of interpretation that may be said to have any practical conclusions - one that would allow us to establish the criteria for a valid interpretation in advance, that is, outside the context of a particular reading: „by ,theory' we mean a special project in literary criticism: the attempt to govern interpretations of particular texts by appealing to an account of interpretation in general" (Knapp \& Michaels 1982, 723). This means that there can also be no method of reading, no general instruction on how we should read in order to produce valid interpretations. At the end of the day, everyone reads and interprets in the same manner-even though some may deny it-and thus literary criticism may have no method.

We can see how from the very beginning Michaels' and Knapp's project bore a certain resemblance to materialism as understood by Jameson. Against Theory, and the articles that followed, provide us only with a set of negative tools, a way of "demystifying and de-idealising” such concepts as literature, meaning or interpretation. It does not offer a „new way” of reading texts; indeed, it openly claims that such a thing

in relation to "positive theorists," i.e. those who see the meaning as dependent on the author's intention. This is, of course, an inherently theoretical position, and it is explicitly opposed by Knapp and Michaels. In the following decades, however, the term ,intentionalism" has been reused as a shorthand for an approach to literary studies proposed in Against Theory. I use the term "strong” intentionalism to differentiate between Michaels' original position and various later attempts at „softening” the radicalism of his initial argument; see e.g. Goldsworthy 2005. 
is strictly impossible. The authors start their A Reply to Our Critics with an explicit statement that if their critics were right in their account of the „consequences” stemming from Against Theory, this „would already amount to a radical objection to an argument that explicitly denies having any consequences for the practice of literary criticism" (Knapp $\&$ Michaels 1983, 791). The only practical conclusions one can derive from their argument, they suggest, is entirely dependent on the institutional context — as long as literary theory exists, as long as people believe in the theoretical (or, should we say, idealist) illusion, the primary argument made in Against Theory' remains valid and indeed politically urgent. But it has no validity of its own, so to speak; it is solely polemic and negative-a criticism rather than a description of how to do criticism.

Theory attempts to solve — or to celebrate the impossibility of solving — a set of familiar problems: the function of authorial intention, the status of literary language, the role of interpretive assumptions, and so on. We will not attempt to solve these problems, nor will we be concerned with tracing their history or surveying the range of arguments they have stimulated. In our view, the mistake on which all critical theory rests has been to imagine that these problems are real. In fact, we will claim such problems only seem real—and theory itself only seems possible or relevant-when theorists fail to recognize the fundamental inseparability of the elements involved (Knapp \& Michaels, 723-724)

Like materialists, who insist on inseparability of material processes and various spheres of cultural, social and everyday life, Michaels and Knapp seek to remind us of the theory's inability to simply think up distinctions, contradictions and relationships where no such things exist or may exist.

However, by focusing on this negative aspect, on the superficial (yet, I believe, ultimately quite important) similarities between Against Theory and Jameson's understanding of materialism, we risk getting ahead of ourselves, or, rather, reading Michaels' and Knapp's original argument in reverse, starting with its institutional consequences rather than its ontological and epistemological basis. The anti-methodical side of their project is not, after all, its most controversial point; their account of meaning and interpretation is:

The clearest example of the tendency to generate theoretical problems by splitting apart terms that are in fact inseparable is the persistent debate over the relation between authorial intention and the meaning of texts. Some theorists have claimed that valid interpretations can only be obtained through an appeal to authorial intentions. This assumption is shared by theorists who, denying 
the possibility of recovering authorial intentions, also deny the possibility of valid interpretations. But once it is seen that the meaning of a text is simply identical to the author's intended meaning, the project of grounding meaning in intention becomes incoherent. Since the project itself is incoherent, it can neither succeed nor fail; hence both theoretical attitudes toward intention are irrelevant. (Knapp \& Michaels, 724)

The meaning and the author's intention are one and the same; they are not „identical” in the sense of one being extremely similar to the other, to the point of indistinguishability — rather, they are simply two names for the same thing. This is why it doesn't really matter whether one believes that meaning is independent (partly or totally) of the author's intention, or that meaning can be deciphered through the analysis of the author's intention; in both cases, one has already committed to seeing meaning and author's intention in terms of a link, or a relationship (be it a positive or a negative one) between two separate „things”, and this is, Knapp and Michaels say, precisely the original sin of all theory.

But what about - we're doomed to ask if only for the fact that by now we've internalised most of theory's basic assumptions-such things as intentionless meaning, the meaning of the text itself, the meaning of the language-system, a reader's own meaning and so on? What about the common empirical observation that readers often disagree as to the fundamental meaning of the text, and in practice there is no one who could solve their arguments once and for all, no ultimate figure of interpretative authority?

Knapp and Michaels seek to explain the core of their argument through an illustrative example —an imagined everyday scenario—of the well-known ,wave poem”:

Suppose that you're walking along a beach and you come upon a curious sequence of squiggles in the sand. You step back a few paces and notice that they spell out the following words:

A slumber did my spirit seal;

I had no human fears:

She seemed a thing that could not feel

The touch of earthly years.

This would seem to be a good case of intentionless meaning: you recognize the writing as writing, you understand what the words mean, you may even identify them as constituting a rhymed poetic stanza-and all this without 
knowing anything about the author and indeed without needing to connect the words to any notion of an author at all. You can do all these things without thinking of anyone's intention. But now suppose that, as you stand gazing at this pattern in the sand, a wave washes up and recedes, leaving in its wake (written below what you now realize was only the first stanza) the following words:

No motion has she now, no force;

She neither hears nor sees;

Rolled round in earth's diurnal course,

With rocks, and stones, and trees.

One might ask whether the question of intention still seems as irrelevant as it did seconds before. You will now, we suspect, feel compelled to explain what you have just seen. Are these marks mere accidents, produced by the mechanical operation of the waves on the sand (through some subtle and unprecedented process of erosion, percolation, etc.)? Or is the sea alive and striving to express its pantheistic faith? Or has Wordsworth, since his death, become a sort of genius of the shore who inhabits the waves and periodically inscribes on the sand his elegiac sentiments? You might go on extending the list of explanations indefinitely, but you would find, we think, that all the explanations fall into two categories. You will either be ascribing these marks to some agent capable of intentions (the living sea, the haunting Wordsworth, etc.), or you will count them as nonintentional effects of mechanical processes (erosion, percolation, etc.). But in the second case-where the marks now seem to be accidents—will they still seem to be words?

Clearly not. They will merely seem to resemble words. (Knapp \& Michaels, 727-728)

This example allows Knapp and Michaels to establish a clear link between not only meaning and an (imagined, or posited) author, but between the author and the very identity of the text. In other words, the only reason why we can talk of texts and language, the only reason why we perceive text as text—or language as language—is that we posit an author behind every text, speech or utterance; and as soon as we no longer imagine an author behind them, we cease to perceive them as such:

As long as you thought the marks were poetry, you were assuming their intentional character. You had no idea who the author was, and this may have tricked you into thinking that positing an author was irrelevant to your ability 
to read the stanza. But in fact you had, without realizing it, already posited an author. It was only with the mysterious arrival of the second stanza that your tacit assumption (e.g., someone writing with a stick) was challenged and you realized that you had made one. Only now, when positing an author seems impossible, do you genuinely imagine the marks as authorless. But to deprive them of an author is to convert them into accidental likenesses of language. They are not, after all, an example of intentionless meaning; as soon as they become intentionless they become meaningless as well.

The arrival of the second stanza made clear that what had seemed to be an example of intentionless language was either not intentionless or not language. The question was whether the marks counted as language; what determined the answer was a decision as to whether or not they were the product of an intentional agent. (Knapp \& Michaels, 728)

From this single argument stem countless consequences, both philosophical as well as practical and political, of which at least a few seem hugely relevant in our discussion of materialism and literary criticism. According to Michaels and Knapp, texts_-including all of the fictional characters, spaces, events etc. within them; everything that constitutes their „content”- exist only as an expression of the author's intention. They are not autonomous or semi-autonomous or intersubjective, they are not „objects” in their own right; and the fact that they are being interpreted in various ways does not mean that they have alternative meanings, or that these meanings depend on the reader. In fact, the assumption that they do, although common in contemporary academia, stems from the theory's inability (or unwillingness) to distinguish between the epistemological and the ontological. Knapp and Michaels point this out perhaps most clearly in their criticism of deconstruction in Against Theory 2:

In one sense the claim that intention cannot govern the scene of utterance seems to us correct. Even if, as we have argued, intention determines meaning, there can be no guarantee that the intended meaning will be understood. To say that the author cannot govern the scene of utterance is only to say that the author cannot enforce communication. A speaker or writer can always fail to communicate; misinterpretation is always possible. (Knapp \& Michaels 1987, 61)

The plurality of interpretations, whose existence no one sane would try to put in doubt, does in no way imply a plurality of meanings, just like the fact that no one understands a certain text does not mean that it has no meaning. These are all essentially practical issues to do with communication - rather than ontological issues to do with the nature 
of meaning. Contrary to what Derrida thought, the fact that a single text may have many different interpretations is actually a proof of exactly that - for if every reader was able to produce their own meaning, they would be in fact reading different texts (seeing as meaning is the only thing that lets us identify language as language).

In other words - to sum up the basic tenets of Knapp and Michaels' original argument - as soon as we recognise language as language, we posit (though not always consciously) some author, „an intentional agent," and some meaning, vague though our understanding of it may be. This doesn't necessarily mean that our interpretation is valid, or indeed that it ever may be entirely valid; it just means that we cannot „step outside" of our own belief that it is. Accounting for the fact that we may be wrong - questioning ourselves, confronting ourselves with new evidence, testing out various alternative hypotheses etc.- - is vastly different from trying to suspend or circumvent our own beliefs through a theoretical operation. This is why, for Michaels, the issue of interpretation is one of belief. A true pragmatist understands that their knowledge on how various opinions and beliefs are shaped-e.g. that everyone, including themselves, is affected by various types of conscious and unconscious bias-does not allow them to occupy a position outside of their own particular beliefs, one from which they could in practice see all beliefs as essentially equal (as in, equally unfounded). The theory that reminds us that our beliefs (and our interpretations) are in principle no more or less founded than the beliefs (and interpretations) shared by other people, does in no way allow us to suspend what we believe in; the only way we can change our own beliefs is through practical means, rather than a sheer act of our theoretically_or politically_motivated will.

And such a suspension is exactly what the new materialist literary criticism would have us do. This is, after all, the essence of Levi Bryant's call to understand fictions in terms of „what they are” in addition to „what they are about," or Eileen Joy's implicit demand that we restrain ourselves from interpreting the texts we encounter in order to appreciate the weird „remainder” of the „chatter and noise." Or we could compare Knapp and Michaels' wave-poem to Cohen's toad-rock-his arbitrary privileging of the moment of surprise and uncertainty, his substitution of the epistemological (the observer's uncertainty as to whether they have in front of them a rock or a toad) for the ontological (the idea that the rock and the toad henceforth share a special bond) that stands in stark contrast to the clarity of the argument presented in Against Theory: that the reality neither shifts according to the ebbs and flows of our 
thought, nor allows us to stand outside what we believe at any given moment. As soon as we know whether the wave-poem was a random occurrence or genuine writing-whether what we saw was a rock or a toad-there's no going back to that fleeting moment of wondrous contemplation. It's not that the reality is back to normal, it's that nothing has really happened in the first place; the lines in the sand were never truly a poem, and the toad was never truly a rock (or the other way round, obviously).

\section{Huckleberry Finn, or Texts as Objects}

But this is not the only way in which Michaels' criticism allows us to critically examine the basic tenets of the new materialist discourse on literature. He also reminds us of the importance of the distinction between objects and texts; between things that may be reduced to their physicality and those that base their very identity on having meaning. On the first page of The Shape of the Signifier, he famously discusses the curious case of the facsimile edition of Emily Dickinson's poetry:

For the very idea of textuality depends upon the discrepancy between the text and its materiality, which is why two different copies of a book (two different material objects) may be said to be the same text. The text is understood to consist in certain crucial features (e.g., [and minimally] certain words in a certain order), and any object that reproduces those features (whatever they are thought to be) will reproduce the text. One way to criticize an edition, then, is to criticize it for failing to recognize and reproduce the crucial features, and some of Howe's criticisms of Johnson take this form. But her sense of Dickinson's poems as drawings and her commitment to the "physical immediacy" of them as objects involve a more radical critique, since insofar as the text is made identical to the "material object," it ceases to be something that could be edited and thus ceases to be a text at all. (Michaels 2004, 3)

This is why, while Michaels' stance is incompatible with the new materialist project, it still allows for a reading that pays particular attention to what the author intentionally does with the materiality of any given medium —or reading „for weirdness," we could say, as opposed to Joy's „weird reading." To paraphrase Michaels' remarks on the affective turn in literary studies: materiality matters insofar as it is supposed to matter; reading for materiality is just reading.

However, a world where all texts may be seen as objects, and vice 
versa, is, according to Michaels, an essentially neoliberal one: the conflict- and ideology-based politics of class struggle have been replaced here by a non-politics of basically interchangable identities, or subject-positions, and no real challenge to the capitalist status quo is possible. But this line of argument from The Shape of the Signifier is well-known; what we should draw our attention to is the ease with which the new materialists convert texts into objects.

Levi Bryant, for instance, doesn't even seem to think it's necessary to provide a detailed account of a passage from object to text, or possible differences between the two; for him, the status of text as an object is self-evident: „The hypothesis of a virtual text behind or within manifest texts suggest that the text as such is independent of any of its manifestations, but also independent of its author or origin (after all, text is an object in its own right)" (Bryant 2010). Something similar happens in Eileen Joy's You Are Here: a Manifesto, where the analogy between a body and a text is offered as self-evident and not requiring proof: „The human body is itself a time capsule of all previous bodies, just as texts are time capsules of all previous writing, and the "junk" - whether junk-DNA or spilled ink in the margins, is always with us" (Joy 2012, 166). The example of „spilled ink” seems particularly interesting when we remember that the issue of the textual status of such ,junk" is a starting point for The Shape of the Signifier. What Michaels points out is that things such as ink-stains can be only seen as parts of the text if we ascribe meaning to them, if we see them as intentional and not random. And indeed, in practice we tend to think of the author's manuscript and the finished copy of their book as two instances of the same text, even though it must be assumed that there are huge physical differences between the two, and many ,junk-like” elements of the former don't ever make it into the latter.

The widespread assumption that texts are essentially objects seems to stem at least partly from the work of Graham Harman, specifically his essay The Well-Wrought Broken Hammer: Object-Oriented Literary Criticism (2012). As a rule of thumb, Harman — as well as many of those advocates of the object-oriented ontology who see it as a separate movement in philosophy and criticism, rather than just a part of larger spectrum associated with the „material turn”-offers a view of literature and art that's closer to Michaels' brand of intentionalism than most of the „new materialists”' . Harman's comments on Wimsatt and Beardsley's

3 Another example would be Timothy Morton, the author of An Object-Oriented Defense of Poetry (2012), who explicitly rejects any materialist label, but 
notion of „intentional fallacy," for instance, seem quite close to, if less precise than, those articulated by Jennifer Ashton, another „strong” intentionalist critic associated with Nonsite.org (see Ashton 2011; Harman 2012, 201); and his comments on object-oriented ontology as a „countermethod" that would prevent us from „dissolving a text upward into its reading or downward into its cultural elements", and focus instead „on how it resists such dissolution," may almost seem like a fitting prelude to Against Theory.

Nonetheless, Harman quickly assumes that texts may be seen as essentially similar to objects (as understood within the framework of object-oriented ontology) and at no point challenges this assumption. Like Skiveren, he sees the fact that a work of literature is seemingly never fully understood as a proof of it being essentially withdrawn not only in relation to any particular interpretation, but meaning as such. In other words, he mistakes the epistemological for the ontological, and the impossibility of a perfect paraphrase for the lack of meaning, or, rather, for a textual "excess" that provides the text with an identity outside of its author's intention: ,the autonomy and integrity of the object in no way implies the autonomy and integrity of our access to the object. The literary text runs deeper than any coherent meaning, and outruns the intentions of author and reader alike" (Harman 2012, 200). This is why he may compare a poem to a too- admittedly, not just any tool, but Heidegger's famous hammer:

The object-oriented side of Brooks can be found in his hostility to paraphrase. A poem cannot be translated into literal prose statement: "All such formulations lead away from the center of the poem-not toward it." Any attempt to summarize the literal meaning of a poem inevitably becomes a long-winded effort, filled with qualifications and even metaphors, a lengthy detour that comes more and more to resemble the original poem itself. (...) The poem differs from any literal expression of its content just as Heidegger's hammer itself differs from any broken, perceived, or cognized hammer. It is not just that the poem or hammer usually acts as an unnoticed background that can then be focused on explicitly from time to time. Instead, the literal rendition of the poem is never the poem itself, which must exceed all interpretation in the form of a hidden surplus. (Harman 2012, 189)

who seems to do so in relation to a specifically new materialist understanding of materialism, i.e. he assumes materialism to be simply idealism in reverse, and so opts for the term „realism” instead. The issue of the relationship between realism and materialism, important also to Graham and speculative realists in general, lies obviously outside the scope of this essay. 
But this is a hasty comparison. Texts may resemble hammers in that Heidegger had presumably very limited access to both in his hut in the Black Forest, but there are important ontological differences between the two. We may use a hammer regardless of whether any part of our brain realises we're using it and whether we recognise it as a hammerthe same way a chair may be identified as a chair and used as a chair regardless of whether we know it represents a result of the carpenter's intention to actually build a chair. We can throw a rock through someone's window without paying any thought to the origins of either the rock or the window. But texts only exist as texts as long as they have a meaning, i.e., an author capable of having intentions; they don't „work” regardless of whether we recognise them for what they are, the way a hammer does. That's why they can be abstracted from any particular physical vehicle-something that hammers can't do. In the context of language, Harman's "hidden surplus” is thus nothing more than a meaning that we haven't yet understood.

But the eagerness to turn texts into objects—or objects into textsis in no way limited to those who affiliate themselves to some extent with either speculative realism in general or Harman's object-oriented ontology in particular. Indeed, although Tobias Skiveren wants to see the focus on "recasting the materiality of the signifier as the materiality of the object" as the main criterion for differentiating between a speculative realist literary criticism and its "proper” new materialist counterpart (Skiveren 2018), the whole issue seems slightly more complicated than that, and the line dividing the two quickly becomes blurred. In Weird Reading, for instance, Eileen Joy starts by aligning her own position with that of speculative realism, only to then explicitly reference Vibrant Matter as a crucial influence: „I'm influenced by Jane Bennett's "vibrant" materialism in which objects, which could be texts, are seen to ,act as quasi agents or forces with trajectories, propensities, or tendencies of their own,' outside of human will and human design" (Joy 2013, 30). Although Bennett herself may emphasise, in her reply to Harman and Morton, the fact that texts constitute a very particular type of objects - that ,there are also, it seems, some features of the text-body that are not shared or shared differentially by bodies that rely more heavily on smell and touch" - she seems to have no doubt that texts are essentially objects, or bodies: „like all bodies, these literary objects are affected by other bodies (...)" (Bennett 2012, 232). Here, the difference between speculative realists and new materialists "proper” may be of interest to those personally invested in either movement, but seen from the outside, these two seem to share many of the assumptions as to the 
object-like nature of all texts.

The ease with which new materialists seem to convert objects into texts and vice versa, points to yet another contradiction within any potential project of a new materialist literary criticism - namely, its desire to preserve the notion of texts as separate entities while detaching them from the only thing that provides them with their separate identities, that is, meaning. When it comes to literature (and possibly art in general), new materialists like Joy and Bryant seem to want to have their ontological cookie and eat it too: deprive texts of their fixed identities, abolish the old boundaries and root fictions in the ever-undetermined flux of material life-but still inhabit a world where it's perfectly acceptable to talk about both particular texts and literature in general. Bryant, for instance, articulates this desire this in terms of „openness":

The various strategies of humanist criticism-hermeneutic, biographical, historical, new historicist, psychoanalytic, Marxist, etc. - can all be seen as strategies for closing texts, for reducing the signal to noise ratio, by fixing meaning behind the entropic play of the text in its polysemy. What this style of criticism strives for is a crystallization of the fixation of the text. (Bryant 2011b)

We should thus strive, Bryant seems to suggest, to preserve texts as texts, while simultaneously leaving them „open” or "unfixed” in their "polysemy." But considering that texts exist only insofar as they are an expression of particular authorial intentions, this is obviously impossible. We can either discuss literature or indulge in an imagined textual "polysemy"-not both.

We could probably dismiss these parts of the new materialist project as a particularly outrageous case of wishful thinking, were it not for the fact that the stake is very explicitly political:

Here I am reminded of debates surrounding "revisionist criticism" that took place in the 90s when I was still in High School. There the big scandal was that an English professor somewhere had argued that Mark Twain's Huckleberry Finn was really an allegory for a socially repressed homosexual relationship between Huck and Jim. Among the humanists the sparks flew. "This could not possibly be what Twain meant! This is a travesty!" Similar things occurred with Shakespeare. Yet from the standpoint of object-oriented criticism, the question of whether Twain meant this is irrelevant. All that is relevant is that Huckleberry Finn has the power, the capacity, to construct or produce this sort of reading, allowing for the illumination of parallels between black oppression and homosexual oppression, allowing for us to broaden the notion of "queer" as representative of any anomalous or rogue part of a social situation that goes uncounted 
(...), allowing for the construction of heroic subjectivities such as we find in Huck and Jim (Bryant 2011b)

Of course, what this mode of criticism appreciates in practice, is not the „textual object's” autonomy - its ability to produce its own unexpected meanings_-but the reader's ability to re-write the text so it fits a particular theoretical jargon, or a particular political purpose. When it comes to interpretation, there is no functional difference between interpretative constructivism/subjectivism - a belief that readers' produce meanings for the texts they read—and materialism „as literalism”, i.e. one that attributes such production to the text itself. Michaels explains this in The Shape of the Signifier:

The effort here has been to think through the question not only of what a text means but, even more fundamentally, fundamentally, of what the text is - of what is in it and what isn't, what counts as part of it and what doesn'twithout the appeal to the author's intention. And the point is that if you do this, you find yourself committed not only to the materiality of the text but also, by way of that materiality, to the subject position of the reader. You find yourself committed to the materiality of the text because, if you don't think it matters whether the author of the text did or didn't intend the eighty-six blank pages to count as part of it, the mere fact that they are there must be dispositive. And you find yourself committed to the primacy of the subject position because the question about what's there will always turn out to be (this argument is made at length later) a question about what's there to you, a question about what you see. Once, in other words, the eighty-six pages count not because some author meant them to count but because they are there, in front of you, then everything that is there must also count - the table the pages are on, the room the table is in, the way the pages, the table, and the room make you feel. Why? Because all these things are part of your experience of the pages, and once we abjure interest in what the author intended (once we no longer care whether or not the author intended us to count the room the work of art is in as part of the work of art), we have no principled reason not to count everything that's part of our experience as part of the work.

(...)

So the argument, in miniature, is that if you think the intention of the author is what counts, then you don't think the subject position of the reader matters, but if you don't think the intention of the author is what counts, then the subject position of the reader will be the only thing that matters. (Michaels 2004, 10-11)

(New materialists seem to understand this functional interchange- 
ability quite well; Joy's „weird reading” relies on distributing agency between the reader and the text itself, as if both operations were complimentary rather than contradictory: „the experience of narrative is also a rapprochement with a ,persisting object' that uses humans as an activation device, a sort of on-switch. We might tentatively qualify literature as a 'quasi-object' that is neither entirely an object nor either fully a subject but is nevertheless in the world as a "constructer of intersubjectivity"' [Joy 2012, 165]).

Bryant's example is very instructive in that it forces us to distinguish between the ostensibly progressive nature of a particular reading of $\mathrm{Huc}$ kleberry Finn and the undemocratic and implicitly elitist theoretical position from which it stems and which it ultimately helps to reproduce. If Huckleberry Finn has no objective meaning and no fixed identity, then "the power, the capacity, to construct or produce" any reading must surely belong to the interpreter rather than the text itself. And considering that in practice we cannot escape meaning and interpretation, what really happens in Bryant's scenario is the empowerment not of the text itself, but of a particular type of reader: one who can manipulate the meaning for their own political purposes in a way that bears some resemblance to a valid interpretation, and also remains credible in the context of the current political hegemony (be it local or global). In other words, Bryant's vision seems to promote a type of a well-educated, possibly academic reader who's perfectly aware of what the text actually means, but has enough rhetorical skill to bend it to their particular political agenda and enjoys a position of authority that allows them to move within the established institutions with a certain degree of freedom. This is, obviously, nothing new-if anything, it only serves to remind that when it comes to literature, new materialists seem to frequently rely on some very post-structuralist ideas about reading, interpretation and meaning-production.

Meanwhile, accepting the basic tenets of Michaels' intentionalism doesn't solve, in and of itself, all our political problems; even if we all embraced Against Theory overnight, it wouldn't automatically bring in a new reality, abolish old hierarchies or introduce a new egalitarian society. Indeed, the point that Knapp and Michaels make is that no account of what interpretation is or does can ever do such a thing. We cannot circumvent our political arguments by developing a new literary theory. But Michaels' argument lays the groundwork for a critical debate that would be more inclusive, more democratic — and decisively more political - than the ones new materialisms have to offer: one where all sides, irrespective of their rhetorical skills, their relation to political 
hegemony as well as their political support, could assert the importance of their interpretations based on a simple claim to truth. This, far from being a conservative or a reactionary proposition, is in fact a way of resisting the capitalist hegemony. In his last book, Michaels reframes this argument in terms of commodification and the art's ability to resist it:

There are things the artist can't do. He can't determine the price at which it sells or the uses to which it's put; he can't control the effects it generates. And in an art that imagines itself to affirm matter and refuse form, both the impossibility and the irrelevance of this control are thematized, not to say celebrated. But, of course, the work of art can also have one thing that the commodity and sheer matter cannot. And that one thing - the only thing about the work of art that is not determined by its buyers, the only thing about it that belongs only to it, the only thing about it that's not reducible to the commodity it otherwise isis its meaning. (Michaels 2015, 102-103)

Only now do we see that the allegedly egalitarian vision, offered by the new materialists in their discourse on language and literature, is based on a radical affirmation of commodity fetishism - an affirmation that serves to make invisible the very status of commodities, by ascribing to them precisely the single thing that could resist being transformed into a commodity. Theirs is a vision of a weird democracy where the line between citizens - as potential authors, able to speak their mind and argue about ideas — and commodities becomes intentionally blurred.

\section{Wave-poem, or a Different Materialism}

For all its declared negativity and polemic nature, Michaels' intentionalism achieves something that any new materialist literary criticism sets out to achieve, yet always seems to fail to achieve-it roots literature firmly in our shared material reality, putting all of its constituent elements on "the same ontological footing” (albeit in a way that's not necessarily satisfactory for those committed to a „story-laden reenchantment” of the world). And it does so in a way that does not exclude in advance a possibility of non-human or post-human authors or agents.

To understand this part of the argument, we must remember what Michaels and Knapp mean by the phrase „author's intention”-or, more precisely, what they do not mean by it. Firstly, „intention” does not mean here-and this is one of the most often misunderstood parts of the 
original essay-a process that's necessarily conscious, rational etc. Secondly, ,author” doesn't necessarily refer to any particular type of subjects.

It might seem plausible to suppose that an identification of meaning with the author's intention provides theoretical support for the historian's sense of the value of such documents. While historical evidence of this kind might well be valuable, nothing in the claim that authorial intention is the necessary object of interpretation tells us that it is. In fact, nothing in the claim that authorial intention is the necessary object of interpretation tells us anything at all about what should count as evidence for determining the content of any particular intention. To think, for example, that only the poem and no other document should count as evidence of the poet's intention is just as consistent with the thesis that intention is necessary. Recognizing the inescapability of intention doesn't tell us which documents, if any, are the important ones. One could believe that all poetry in every language and every age was written by a universal muse and that therefore no information about any other person could be of any possible interpretive interest - and this too would not be incompatible with the necessity of intention. (Knapp \& Michaels 1983, 796)

In our view, the object of all reading is always the historical author's intention, even if the historical author is the universal muse. That's why we don't think it makes sense to choose historical intention-and why we don't think it's possible to choose any other kind of intention. (Knapp \& Michaels 1983, 798)

There is nothing in Against Theory itself that would preclude us from asking whether animals (or robots, or corporations) are subjects capable of intentions. And whereas we can deduce Michaels' opinion on many of these issues from his other writings, Against Theory has something crucial to say about the very way in which we should approach the issues of non-human authorship. Tempting as it may be, there's no point in trying to answer these questions within the framework of literary theory (by referring to an account of meaning and interpretation); they need to be seen for what they are, as questions about subjects and subjectivity rather than texts and textuality.

The best example of how this approach works in practice may be Michaels' comments on psychoanalysis and the unconscious from Gold Standard:

The discovery of the unconscious thus problematizes agency only to extend it, finding actions where only accidents had been. (Michaels 1987, 222) 
And here we find ourselves at the site of a certain rapprochement between the compulsion to gamble and the Freudian compulsion not to let chance count as chance: the effect of both is to make actions interesting by making them at least temporarily indeterminate. Freud (like Lawrence Selden) does this by extending the range of actions, transforming „slips" into the expression of unknown intentions. (Michaels 1987, 236)

The discovery of the unconscious transforms not our account of meaning (by substituting intentions for something else), but our knowledge of who the authors may be. Or, to put it in slightly blunt terms, psychoanalysis tells us that the unconscious is also capable of intentions. The range of possible authors is thus „extended” to include a larger part of our psyche.

Within the framework offered by Michaels, defending the idea of „storied matter" requires that its advocates point out specific intentional agents behind its "stories." In other words, you cannot simply wish post-humanist literature into being: you need to find post-human authors first. If, for instance, one proposes that we treat global pollution as a story (Iovino \& Oppermann 2014, 8), one needs to prove that it indeed is a story-i.e. that it serves as a means of expression of an intention of a particular author-and not simply that it could be seen as a story if we took it out of the really existing context. If someone remains convinced that "the natural world is perfused with signs, meanings, and purposes which are material and which evolve" (Iovino \& Oppermann $2014,4)$, they need to point out who put those signs and meanings there-instead of pointing out that under certain circumstances, for a fleeting moment it might seem as if someone put them there. This both limits and liberates a potential discussion on non-human authors. What Michaels' criticism offers is a simple rejection of all attempts at solving the crucial issues of subjectivity and agency on the grounds of literary or cultural theory-we need to approach them in practice, using our common sense and practical everyday knowledge, as well as all the relevant tools from various research fields and disciplines; we cannot simply theorise these issues away. Reading the natural world as if it had meaning does not answer any of the important questions to do with non-human agency; treating the world around us as if it was story-laden says nothing about the forms of agency present in the natural world (or in things). No author has any more claim to "materiality" than any other; all texts are material, in that they express real intentions of existing authors; meanings exist independent of our interpretations-this is the literature's shared ontological footing that the new materialists have been looking for. 
It's worth noting that although Michaels is a committed socialistand a class-struggle socialist, rather than a ninety-nine-percenter, at that-he is, strictly speaking, no Marxist; he comes from a different, Anglo-American tradition of political radicalism and philosophical pragmatism. But his understanding of language nonetheless echoes the well-known remarks from The German Ideology on the social nature of all language:

Language is practical consciousness that exists also for other men, and for that reason alone it really exists for me personally as well; language, like consciousness, only arises from the need, the necessity, of intercourse with other men. Where there exists a relationship, it exists for me (Engels \& Marx 1974, 51)

There is obviously a lot to unpack in this quote, and a detailed interpretation would require that we elaborate on the notions of consciousness, practice, and necessity, as they appear in Marx. But we don't need to go into detail in order to point out obvious similarities to Michaels' understanding of language and literature: that they exist only as a result of our need to communicate, always concrete, always already entangled in the web of social relations, and never as something to be observed from the outside.

\section{Ending, or the Fight Continues}

The issue of materialism - the very term materialism — is conspicuously absent from most of Michaels' writing. Where it appears, it is usually in the sense that's much closer to new materialisms than historical materialism: in Our America, Michaels comments on the "materialism” of William Carlos Williams' poetic, ,its commitment to the idea that the poem's identity consists in its material features" (Michaels 1995, 83); in The Shape of the Signifier, it's Paul de Man, Michaels' arch-enemy, who earns the name of a materialist (Michaels 2004, 9). But in The Beauty of a Social Problem, we can see a subtle shift-Michaels still uses the term „materialism” to refer to what Eagleton would call its „postmodern” version, but now the exact term is "materialism-as-literalism”, as if Michaels realised that the materialist label should not be conceded to his opponents that easily.

Of course, one shouldn't overestimate the importance of such largely academic labels; it could be even said that to approach criticism from a materialist perspective means exactly that - remembering that some 
Rather, what is interesting is precisely the reason for how two very different approaches to criticism may co-exist under the same name: in other words, how superficial similarities, reinforced by vague allusions to common sense or a certain political sensitivity, may

be used to cover up more substantial differences to try and turn old enemies into very uneasy allies. As far as the specific issue of materialism is considered, this scenario is particularly interesting in the context of contemporary literary studies. if not most things do not change simply because we put a certain label on them. Rather, what is interesting is precisely the reason for how two very different approaches to criticism may co-exist under the same name: in other words, how superficial similarities, reinforced by vague allusions to common sense or a certain political sensitivity, may be used to cover up more substantial differences to try and turn old enemies into very uneasy allies. As far as the specific issue of materialism is considered, this scenario is particularly interesting in the context of contemporary literary studies. Here, as I have tried to show, the materialist label is being used today to reproduce and reinforce the original sin of theory with all its political consequences, to push for an ever more „reenchanted" and alienating image of literature, art and reality, and to force categories such as meaning and interpretation even further into the background of the academic mainstream. The same label, however, may be of use in our efforts to resist, oppose and criticise this very process through the work of „demystification and de-idealisation.” There is still much to fight for, and we should allow neither jumping rocks nor quantum physics to convince us otherwise.

\section{References}

Ashton, Jennifer. 2011. „Two Problems with a Neuroaesthetic Theory of Interpretation". Nonsite.org \#2.

Bednarek, Joanna. 2018. „Różnica epistemologiczna i cięcie sprawcze: materializm marksistowski a nowy materializm”. In Feministyczne nowe materializmy: usytuowane kartografi, edited by Olga Cielemęcka $\&$ Monika Rogowska-Stangret. Lublin: E-naukowiec.

Bennett, Jane. 2012. „Systems and Things: A Response to Graham Harman and Timothy Morton". New Literary History, Volume 43, Number 2, Spring 2012, pp. 225-233.

Bryant, Levi. 2010. „Notes Towards an Object-Oriented Literary Criticism". Larval Subjects (larvalsubjects.wordpress.com), 1.11.2010.

Bryant, Levi. 2011a. Texts are a Factory: Eileen Joy. Larval Subjects (larvalsubjects.wordpress.com), 5.10.2011

Bryant, Levi. 2011b. Speculative Realist Literary Criticism. Larval Subjects (larvalsubjects.wordpress.com), 23.12.2011.

Beetz, Johannes. 2016. Materiality and Subject in Marxism, (Post-)Structuralism, and Material Semiotics. London: Palgrave Macmillan.

Cohen, Jeffrey Jerome. 2014. „Foreword: Storied Matter”. In Material 
Ecocriticism, edited by Serenella Iovino \& Serpil Oppermann. Bloomington: Indiana University Press.

Coole, Diana \& Samantha Frost (eds.). 2010. New Materialisms: Ontology, Agency and Politics. Durham \& London: Duke University Press.

Eagleton, Terry. 2016. Materialism. New Haven \& London: Yale University Press.

Edwards, Jason. „The Materialism of Historical Materialism”. In New Materialisms: Ontology, Agency and Politics, edited by Diana Coole \& Samantha Frost. Durham \& London: Duke University Press.

Goldsworthy, Jeffrey. 2005. „Moderate versus Strong Intentionalism: Knapp and Michaels Revisited”. 42 San Diego L. Rev. 669 (2005).

Graeber, David. 2006. „Turning Modes of Production Inside Out: Or, Why Capitalism is a Transformation of Slavery". Critique of Anthropology Vol 26(1) pp. 61-85.

Harman, Graham. 2012. The Well-Wrought Broken Hammer: Object-Oriented Literary Criticism. New Literary History, Volume 43, Number 2, Spring 2012, pp. 183-203.

Iovino, Serenella \& Serpil Oppermann. 2014. „Introduction: Stories Come to Matter”. In: Material Ecocriticism, edited by Serenella Iovino \& Serpin Oppermann. Bloomington: Indiana University Press.

Jameson, Fredric. 1995. „Marx’s Purloined Letter”. New Left Review 209, January-February 1995, pp. 75-109.

Jameson, Fredric. 2009. Valences of Dialectic. London: Verso.

Joy, Eileen. 2013. „Weird Reading”. Speculations: A Journal of Speculative Realism IV (2013), pp. 28-34.

Joy, Eileen. 2012. „You Are Here: a Manifesto”. In Animal, Mineral, Vegetable: Ethics and Objects, edited by Jeffrey Jerome Cohen. Washington, DC: Oliphaunt Books.

Knapp, Steven \& Walter Benn Michaels. 1982. „Against Theory”. Critical Inquiry, Vol. 8, No. 4. (Summer, 1982), pp. 723-742.

Knapp, Steven \& Walter Benn Michaels. 1983. „A Reply to Our Critics”. Critical Inquiry, Vol. 9, No. 4 (Jun., 1983), pp. 790-800.

Knapp, Steven \& Walter Benn Michaels. 1987. „Against Theory 2: Hermeneutics and Deconstruction". Critical Inquiry Vol. 14, No. 1 (Autumn, 1987), pp. 49-68.

Engels, Friedrich \& Karl Marx. 1974. The German Ideology, trans. n.d., edited by C.J. Arthur. London: Lawrence \& Wishart.

Michaels, Walter Benn. 1987. The Gold Standard and the Logic of Naturalism: American Literature at the Turn of the Century. Berkeley \& Los Angeles: University of California Press.

Michaels, Walter Benn. 1995. Our America: Nativism, Modernism, and 
Pluralism. Durham \& London: Durham University Press.

Michaels, Walter Benn. 2004. The Shape of the Signifier: 1967 to the End of History. Princeton \& Oxford: Princeton University Press.

Michaels, Walter Benn. 2006. The Trouble with Diversity: How We Learned to Love Identity and Ignore Inequality. New York: Picador.

Michaels, Walter Benn. 2015. The Beauty of a Social Problem: Photography, Autonomy, Economy. Chicago \& London: The University of Chicago Press.

Morton, Timothy. 2012. „An Object-Oriented Defense of Poetry”. New Literary History, Volume 43, Number 2, Spring 2012, pp. 205-224. Seymour, Richard. 2010. „Basis and Überbau”. Lenin's Tomb (leninology. co.uk), 15.03.2010.

Skiveren, Tobias. 2018. „Literature”. New Materialism (www.newmaterialism.eu), 07.02.2018.s

Szemen, Imre. 1999. „Introduction: A Manifesto for Materialism”. Essays on Canadian Writing; Summer 1999; 68, pp. 1-18.

Torrant, Julie. 2014. „It Is Time To Give Up Liberal, Bourgeois Theories, Including New Materialist Feminism, And Take Up Historical Materialist Feminism For The 21st Century”. The Red Critique 15,2014.

Vermeule, Blakey. 2010. Why Do We Care about Literary Characters? Baltimore: The Johns Hopkins University Press.

Žižek, Slavoj. 2014. Absolute Recoil: Towards a New Foundation of Dialectical Materialism. London: Verso.

PAWE $Ł$ KACZMARSKI - PhD student at the University of Wroclaw, member of the „Praktyka Teoretyczna” editorial team. His research interests include modern $\&$ contemporary poetry and its political contexts. He has edited several books of poetry (including one anthology and three books of selected poems) and is the (co)editor of „8. Arkusz”, a poetry-focused monthly supplement to „Odra”. He lives in Wrocław.

\section{Address:}

Instytut Kulturoznawstwa Uniwersytetu Wrocławskiego

Szewska 50

50-139 Wrocław

email: pawel.j.kaczmarski@gmail.com

\section{Citation:}

Kaczmarski, Paweł. 2019. „Materialism As Intentionalism: on the Possi- 
bility of a „New Materialist” Literary Criticism”. Praktyka Teoretyczna 4 (34): 191-235.

DOI: $10.14746 /$ prt2019.4.10

\section{Autor: Paweł Kaczmarski}

Tytuł: Materializm jako intencjonalizm. O możliwości „nowomaterialistycznej” krytyki literackiej

Abstrakt: W artykule opieram się na pracach autorek i autorów związanych z tzw. „nowymi materializmami”/zwrotem materialistycznym, by odłowić z nich i porównać różne sposoby myślenia o „nowomaterialistycznej” krytyce literackiej/teorii literatury. Zestawiam następnie te projekty z bardziej tradycyjną perspektywą historyczno-materialistyczną - proponowaną choćby przez Fredrica Jamesona - żeby wskazać pewne zasadnicze różnice między takim podejściem do krytyki, które skupia się na tym, co w tekście rzekomo „prawdziwie” materialne, a krytyką podkreślającą zamiast tego materialny wymiar dzieła literackiego w ogóle (na każdym jego poziomie). Znana, często omawiana marksistowska opozycja między bazą i nadbudową pozwala wskazać jak owe dwa podejścia, pozornie zbieżne czy podobne, mogą w rzeczywistości reprezentować bardzo rózne, sprzeczne wręcz szkoły myślenia i krytyki.

Moim celem nie jest przy tym krytykowanie nowych materialistów za nieumiejętność podtrzymania jakichś marksistowskich domgatów - chce raczej wskazać, że nominalne przywiązanie do materialności tekstu, połączone z pragnieniem stworzenia nowej metody lekturowej, prowadzić może do ustanowienia takiej perspektywy, która nawet na własnych zasadach nie jest w żaden sposób „materialistyczna”.

Opierając się na uwagach Fredrica Jamesona o krytyce materialistycznej jako pracy „demistyfikacji i deidealizacji” raczej niż „pozytywnej” metodzie, przywołuję następnie prace Waltera Benna Michaelsa - jego projekt wydaje mi się przykładem takiej „negatywnej” krytyki materialistycznej, która, zamiast dostarczać nam nowych sposobów „uprawiania” interpretacji, pozwala raczej zwalczać przejawy idealizmu w myśleniu o literaturze.

Słowa kluczowe: materializm, idealizm, intencjonalizm, marksizm, krytyka literacka, baza, nadbudowa 